\title{
APLIKASI BREAK EVEN POINT PADA SISTEM OPERASIONAL KAPAL MOTOR PENYEBERANGAN RODITHA PT. ASDP INDONESIA FERRY (PERSERO) CABANG LEMBAR
}

\author{
Made Wijana, A.A.Alit Triadi, Firza Febriandi \\ Jurusan Teknik Mesin, Universitas Mataram \\ JI. Majapahit No.62 Mataram Lombok Barat NTB \\ Email: wijanamd23@yahoo.co.id
}

\begin{abstract}
This study is intended to analyze the feasibility operation KMP Roditha which owned by PT. ASDP Indonesia Ferry (Limited). Location of research in the trajectory Sheet - Padang Bai, was used the Break Even Point. Collecting a range of cost of KMP Rodita, therefore was known the operating costs, maintenance costs and income from the sale of tickets while one year.

Stepsare used in this research is the analysis of quantitative data, where $i$ would collect the data required in relation to the matter to be investigated, so that research results can be more reliable and credible.

The results of this study indicate that KMP Roditha income in 2010 was Rp. 12,007,178,916, of a total of 504 trips. Break Even Point in 2010 occurred in the 5th month on 213 trips, so that KMP Roditha feasible to operate.
\end{abstract}

Keywords: KMP. Roditha, Break Even Point, Trip and costs.

\section{PENDAHULUAN}

Indonesia merupakan Negara kepulauan atau sebagai Negara maritim dimana peran transportasi laut adalah sangat penting bagi kehidupan sosial. ekonomi, pemerintahan, dan keamanan. Dilihat dari presentase antara perairan dan daratan, diketahui bahwa perairan Indonesia memiliki presentase sekitar $63,21 \%$ dari luasan wilayah Indonesia secara keseluruhan sehingga perlu adanya perencanaan moda transportasi laut sebagai upaya memperlancar kegiatan pelayaran yang sangat diperlukan untuk menghubungkan antar pulau, penjagaan wilayah laut serta penelitian kelautan. Bagi masyarakat Indonesia yang tingkat perekonomiannya masih terbilang rendah, transportasi laut merupakan salah satu alternatif sistem yang sangat penting. Kelebihan kapal laut sebagai alat transportasi laut adalah dapat menjangkau sampai pulau-pulau kecil dengan biaya yang relatif murah dibandingkan dengan transportasi udara.

PT. ASDP Indonesia Ferry (Persero) adalah perusahaan jasa angkutan penyeberangan dan pengelola pelabuhan penyeberangan untuk penumpang, kendaraan dan barang. Fungsi utama perseroan adalah menyediakan akses transportasi publik antar pulau yang bersebelahan serta menyatukan pulau - pulau besar sekaligus menyediakan akses transportasi publik ke wilayah yang belum memiliki penyeberangan guna mempercepat pembangunan.

Selain itu PT. ASDP Indonesia Ferry juga harus bersaing dengan perusahaan pelayaran Indonesia lainnya yang antara lain dari perusahaan pelayaran BUMN dan swasta, juga tidak luput juga persaingan dengan perusahaan pelayaran asing lainnya yang semakin banyak jumlahnya secara gross tonnage di dunia ini dan juga memiliki kualitas yang sangat baik, maka menimbulkan banyak masalah dalam penetapan tarif angkut atau tarif uang tambang, hal ini dikarenakan menyangkut tarif jasa angkutan yang ditawarkan perusahaan pelayaran dan juga tingkat kesesuaian dengan permintaan pasar, namun pada jalur pelayaran di wilayah Indonesia tengah, dengan persaingan armada yang cukup banyak, barang atas muatan hasil industri untuk wilayah Indonesia tengah. Sehingga pada perusahaan PT. ASDP Indonesia Ferry dengan mengoperasikan kapalnya (KMP Roditha) apakah menguntungkan atau tidak, karena itu untuk menyelesaikan atau memecahkan permasalahan tersebut maka digunakanlah teori analisis titik impas atau break even point analysis. 
Analisa break even point memberikan penerapan yang luas untuk menguji tindakan-tindakan yang diusulkan dalam mempertimbangkan alternatif-alternatif atau tujuan pengambilan keputusan yang lain. Analisa break even point tidak hanya semata - mata untuk mengetahui keadaan perusahaan yang break even saja, akan tetapi analisa break even point mampu memberikan informasi kepada pimpinan perusahaan mengenai berbagai tingkat volume penjualan, serta hubungan dengan kemungkinan perolehan laba menurut tingkat penjualan yang bersangkutan.

\section{METODE PENELITIAN}

\subsection{DIAGRAM ALIR PENELITIAN}

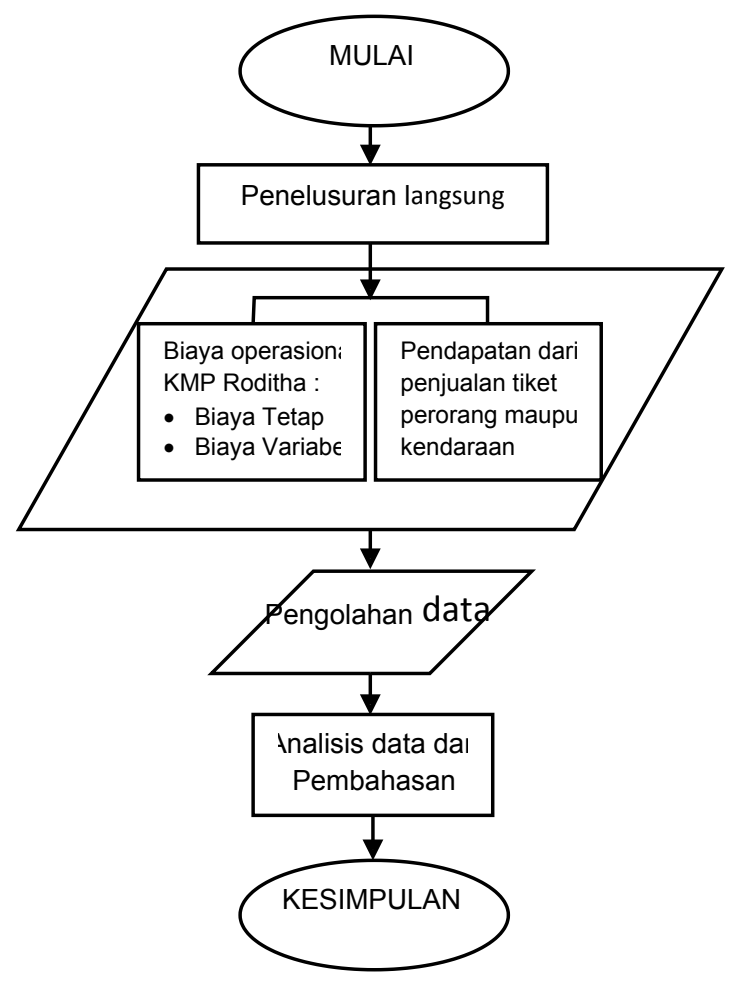

Gambar 2.1 Diagram Alir Penelitian

\subsection{JENIS PENELITIAN}

Penelitian ini menggunakan data kuantitatif, dimana akan dilakukan pengumpulan data berupa angka yang dibutuhkan sehubungan dengan masalah yang akan diteliti, sehingga hasil penelitiannya dapat lebih dipercaya dan diandalkan kebenarannya.

\subsection{PENENTUAN LOKASI PENELITIAN}

Penelitian ini dilakukan di KMP Roditha PT. ASDP Indonesia Ferry (Persero) Kantor Cabang Lembar, Lombok barat.

\subsection{PENELUSURAN PUSTAKA}

Penelusuran pustaka dilakukan untuk mendapatkan data awal seperti penjualan tiket, biaya tetap dan biaya tidak tetap sebagai gambaran penelitian yang akan dilakukan.

\subsection{PENGUMPULAN DATA}

Melakukan pengumpulan data komponen biaya - biaya operasional KMP Roditha langsung dri PT. ASDP Indonesia Ferry (Persero) Kantor Cabang Lembar yaitu:

a. Biaya tetap (fixed cost)
1. Beban SDM
2. Beban Premi Asuransi
3. Beban Penyusutan

b. Biaya variable (variable cost)

1. Beban Operasional
2. Beban Pemeliharaan

Tabel 2.1 Komponen biaya dalam penggunaan KMP Roditha.

\begin{tabular}{l}
\hline Komponen Biaya \\
\hline a. Biaya tetap \\
1. Beban SDM \\
2. Beban Premi Asuransi \\
3. Beban Penyusutan \\
b. Biaya tidak tetap \\
1. Beban Operasional \\
2. Beban Pemeliharaan \\
\hline
\end{tabular}

Tabel 2.2 Komponen pendapatan KMP Roditha.

\begin{tabular}{|c|c|c|}
\hline \multicolumn{2}{|c|}{ Komponen pendapatan } & Nilai \\
\hline \multicolumn{3}{|c|}{ a. Penumpang } \\
\hline \multicolumn{3}{|c|}{ 1. Dewasa } \\
\hline \multicolumn{3}{|c|}{ 2. Anak-anak } \\
\hline \multicolumn{3}{|c|}{ b. Kendaraan } \\
\hline 1. & Gol. I (Sepeda Dayung) & \\
\hline 2. & Gol. II (SPM $<500 \mathrm{cc})$ & \\
\hline 3. & Gol. III (Bemo, SPM >500cc) & \\
\hline 4. & $\begin{array}{l}\text { Gol. IV PNP (Sedan, Minicab, } \\
\text { Minibus s/d } 5 \mathrm{~m} \text { ) }\end{array}$ & \\
\hline 5. & Gol. IV BRG (Pickup s/d 5 m) & \\
\hline & $\begin{array}{l}\text { Gol. V PNP (Bus Sedang s/d } \\
7 \mathrm{~m} \text { ) }\end{array}$ & \\
\hline & $\begin{array}{l}\text { Gol. V BRG (Truck Sedang, } \\
\text { Mobil Tangki s/d } 7 \mathrm{~m} \text { ) }\end{array}$ & \\
\hline & $\begin{array}{l}\text { Gol. VI PNP (Bus Besar } 7 \mathrm{~s} / \mathrm{d} \\
10 \mathrm{~m} \text { ) }\end{array}$ & \\
\hline & $\begin{array}{l}\text { Gol. VI BRG (Truck Besar, } \\
\text { Mobil Tangki } 7 \mathrm{~s} / \mathrm{d} 10 \mathrm{~m} \text { ) }\end{array}$ & \\
\hline & $\begin{array}{l}\text { Gol. VII (Truk Tronton, Tangki, } \\
\text { Kereta penarik } 10 \mathrm{~s} / \mathrm{d} 12 \mathrm{~m} \text { ) }\end{array}$ & \\
\hline & $\begin{array}{l}\text { Gol. VIII (Truk Tronton, } \\
\text { Tangki, Alat Berat, Kereta } \\
\text { penarik dgn ukuran }<12 \mathrm{~m} \text { ) }\end{array}$ & \\
\hline
\end{tabular}




\section{ANALISA DATA}

Untuk menganalisis data digunakan analisa kuantitatif. Analisa kuantitatif digunakan untuk menerangkan atau memberikan penjelasan data - data yang diperoleh dari hasil penelitian. Untuk analisa kuantitatif digunakan rumus Break Even Point untuk mengetahui nilai impas dari pengeluaran dan pendapatan pada KMP Roditha. Berikut adalah rumus Break Even Point yang digunakan untuk mengetahui nilai impas:

a. Pendekatan matematika

$\mathrm{TR}=\mathrm{TC}$

Atau

$\mathrm{pX}=\mathrm{FC}+\mathrm{cX}$

$\operatorname{BEP}(X)=$

di mana :

FC = Biaya Tetap $(\mathrm{Rp})$

$\mathrm{p}=$ Pendapatan perTrip (Rp/trip)

$c=$ Biaya variable perTrip (Rp/trip)

$\mathrm{TC}=$ Biaya total $(\mathrm{Rp})$

TR = Total Pendapatan (Rp)

$X=$ Titik Impas (Trip)

b. Cara grafik

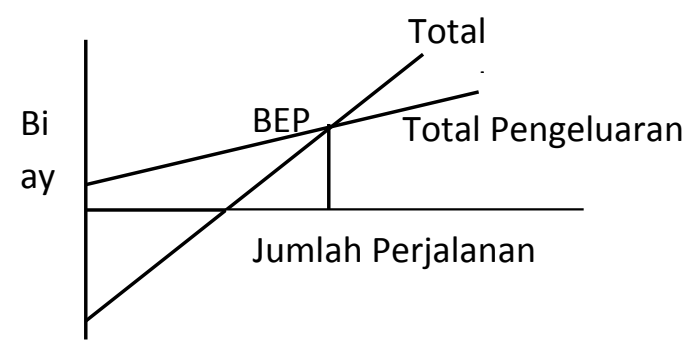

Gambar 2.2 Grafik BEP KMP. Roditha

\section{HASIL DAN PEMBAHASAN}

\subsection{Analisa Biaya pada KMP Roditha}

Biaya pada KMP Roditha terdiri dari biaya tetap dan biaya variable. Pada penelitian ini yang termasuk biaya tetap adalah biaya pemeliharaan, biaya awak kapal, dan biaya premi asuransi. Adapun biaya yang bersifat tetapi bukan unsur biaya tetap adalah biaya penyusutan. Sedangkan yang termasuk biaya variable adalah biaya bongkar muat, pemakaian bahan bakar (solar), pemakaian minyak pelumas (oli), air tawar, dan biaya pelabuhan. Di samping biaya dari KMP Roditha, jadwal perjalanan yang harus di perhatikan.

\section{Jumlah Perjalanan}

Pelayanan angkutan penyeberangan saat ini sudah semakin diperluas. Pada awalnya angkutan ini ditujukan sebagai penghubung antar pulau sebagai pengganti jembatan. Namun perkembangannya jauh lebih pesat, tidak hanya sebagai pengganti jembatan dalam arti jarak pendek, tetapi telah melayani angkutan antar pulau dengan jarak relatif jauh. Akan tetapi, dengan semakin jauhnya jarak angkutan penyeberangan ini, harus pula diikuti dengan jadwal perjalanan yang telah ditentukan.

Tabel 3.1 Jumlah Jadwal Trip KMP. Roditha (Sumber data PT. ASDP Indonesia Ferry Cabang Pelabuhan Lembar - Lombok Barat)

\begin{tabular}{lll}
\hline No. & Bulan & $\begin{array}{l}\text { Jumlah Perjalanan } \\
\text { (Trip) }\end{array}$ \\
\hline 1 & Januari & 33 Trip \\
2 & Februari & 31 Trip \\
3 & Maret & 34 Trip \\
4 & April & 0 Trip \\
5. & Mei & 0 Trip \\
6. & Juni & 0 Trip \\
7. & Juli & 36 Trip \\
8. & Agustus & 77 Trip \\
9. & September & 72 Trip \\
10. & Oktober & 72 Trip \\
11. & November & 72 Trip \\
12. & Desember & 77 Trip \\
\hline Total & & 504 Trip \\
\hline
\end{tabular}

$$
\begin{aligned}
& \text { Rata - rata Trip perbulannya } \\
& = \\
& = \\
& =\text { Trip/bulan }
\end{aligned}
$$

Dari Total Trip KMP. Roditha di dapatkan rata - rata per bulan yaitu 42 Trip/bulan pada tahun 2010.

\section{Biaya Tetap}

Biaya tersebut tetap dikeluarkan oleh modal PT. ASDP Indonesia Ferry pada saat berlayar atau berlabuh dengan atau tanpa muatan. Biaya tetap yang terdiri dari; Biaya Beban SDM, Biaya Beban Premi Asuransi dan Biaya Beban Penyusutan. Adapun biaya - biaya tersebut terdapat pada tabel 3.2, 3.3, 3.4 sebagai berikut :

Tabel 3.2 Beban SDM KMP. Roditha (Sumber data PT. ASDP Indonesia Ferry Cabang Pelabuhan LembarLombok Barat)

\begin{tabular}{ll}
\hline Beban SDM & Total 1 Tahun \\
\hline 1. Gaji, Honor dan & Rp. 613.489.945,- \\
2. Yunjangan & Rp. 84.250.000,- \\
3. Uang Makan & Rp. 421.740.000,- \\
4. Premi Layar & Rp. 61.085.250,-
\end{tabular}




\begin{tabular}{|c|c|}
\hline 5. Pengobatan & Rp. 35.305.234,- \\
\hline 6. Perlengkapan Kerja & Rp. 4.620.000,- \\
\hline 7. Kesejahteraan & Rp. 195.300.436,- \\
\hline 8. Karyaysan & Rp. 37.114.779,-- \\
\hline 9. Dana Pensiun & Rp. 24.959.433,- \\
\hline 10. Tunjangan Hari & Rp. 6.118.012,- \\
\hline $\begin{array}{l}\text { 11. Ғuâak Penghasilan } \\
\text { Pasal } 21 \text { (PPh 21) }\end{array}$ & Rp. 50.186.481,- \\
\hline Total & Rp. 1.534.169.570,- \\
\hline
\end{tabular}

Tabel 3.3 Beban Premi Asuransi (Sumber data PT. ASDP Indonesia Ferry Cabang Pelabuhan LembarLombok Barat)

\begin{tabular}{cl}
\hline Beban Premi Asuransi & Total 1 Tahun \\
\hline 1. Asuransi Kapal & Rp. 45.000.001,- \\
\hline Total & Rp. 45.000.001,-- \\
\hline
\end{tabular}

Tabel 3.4 Beban Penyusutan (Sumber data PT. ASDP Indonesia Ferry Cabang Pelabuhan LembarLombok Barat)

\begin{tabular}{ll}
\hline Beban Penyusutan & Total 1 Tahun \\
\hline 1. Armada Kapal & Rp. 148.750.000,- \\
2. Peralatan Kapal & Rp. 414.882.188,-- \\
\hline Total & Rp. 563.632.188,-- \\
\hline
\end{tabular}

Tabel 3.5 Biaya Tetap KMP. Roditha (Sumber data PT. ASDP Indonesia Ferry Cabang Pelabuhan LembarLombok Barat)

\begin{tabular}{ll}
\hline Biaya Tetap & Nilai (Rp) \\
\hline 1. Beban SDM & Rp. 1.534.169.570,- \\
2. Beban Premi Asuransi & Rp. 45.000.001,- \\
3. Beban Penyusutan & Rp. 563.632.188,-- \\
\hline Total & Rp. 2.142.801.759,- \\
\hline
\end{tabular}

Dilihat dari Tabel 3.2, 3.3 dan 3.4 di peroleh Total Biaya Tetap KMP Roditha yaitu Rp.2.142.801.759,- (Pada tahun 2010, Sumber data PT. ASDP Indonesia Ferry Cabang Lembar).

\section{Biaya Variabel}

Biaya Variabel adalah Biaya yang dikeluarkan pemilik modal selama proses pengoperasian mesin diesel KMP Roditha berlangsung. Biaya ini terdiri atas Beban Operasional dan Beban Pemeliharaan (maintenance)

\section{4 .Beban Operasional}

Dalam penelitian ini, beban operasional yang di keluarkan PT. ASDP Indonesia Ferry Cabang Lembar meliputi biaya pemakaian bahan bakar, biaya pemakaian pelumas, air tawar, dokumen, buku kapal, peta perairan, cleaning service, jasa pelabuhan, dan pengamanan.

Tabel 3.6 Beban Operasional KMP Roditha (Sumber data PT. ASDP Indonesia Ferry Cabang Pelabuhan Lembar Lombok Barat).

\begin{tabular}{lll}
\hline No. & Bulan & Nilai (Rp) \\
\hline 1. & Januari & Rp. 425.663 .766 \\
2. & Februari & Rp. 394.106 .656 \\
3. & Maret & Rp. 396.929 .376 \\
4. & April & Rp. 13.323 .506 \\
5. & Mei & Rp. 1.863 .906 \\
6. & Juni & Rp. 54.694 .290 \\
7. & Juli & Rp. 523.600 .780 \\
8. & Agustus & Rp. 426.875 .640 \\
9. & September & Rp. 508.739.340 \\
10. & Oktober & Rp. 461.056.310 \\
11. & November & Rp. 447.969.040 \\
12. & Desember & Rp. 500.112.380 \\
\hline & Total & Rp. 4.154.934.990 \\
\hline
\end{tabular}

\section{Beban Pemeliharaan dan Perbaikan}

Maintenance adalah kegiatan untuk memelihara dan menjaga fasilitas atau peralatan dan mengadakan perbaikan, penyesuaian dan penggantian yang diperlukan agar terdapat suatu keadaan operasi produksi yang memuaskan sesuai dengan apa yang direncanakan. Setiap perusahaan manufaktur menginginkan agar dapat menggunakan peralatan atau fasilitas produksi setiap saat diperlukan, dalam usaha untuk dapat mempergunakan fasilitas atau peralatan tersebut sehingga kontinyuitas produksi terjamin, maka dibutuhkan kegiatankegiatan pemeliharaan dan perawatan yang meliputi kegiatan perbaikan atas kerusakan mesin yang ada serta penyesuaian atau pergantian spare parts atau komponen yang rusak.

Tabel 3.7 Beban Pemeliharaan dan 


\begin{tabular}{cll}
\hline & \multicolumn{1}{c}{$\begin{array}{l}\text { Perbaikan (Sumber data PT. ASDP } \\
\text { Indonesia Ferry Cabang Pelabuhan } \\
\text { Lembar - Lombok Barat). }\end{array}$} \\
\hline No. & Bulan & Nilai (Rp) \\
\hline 1. & Januari & Rp. 620.000 \\
2. & Februari & Rp. 14.572.500 \\
3. & Maret & Rp. 5.385.000 \\
4. & April & Rp. 223.114.143 \\
5. & Mei & Rp. 1.812.276.243 \\
6. & Juni & Rp. 78.120.000 \\
7. & Juli & Rp. 30.016.200 \\
8. & Agustus & Rp. 137.173.000 \\
9. & September & Rp. 63.164.200 \\
10. & Oktober & Rp. 10.477.500 \\
11. & November & Rp. 379.477.185 \\
12. & Desember & Rp. 19.122.525 \\
\hline & Total & Rp. 2.773.554.273
\end{tabular}

Perawatan pada bagian motor penggerak yang merupakan motor diesel, berdasarkan penelitian diketahui perawatan yang dilakukan adalah docking tahunan, pemeliharaan deck, pemeliharaan mesin, pemeliharaan peralatan kapal, pemeliharaan alat keselamatan dan mobilisasi dalam rangka docking. Rp. 2.773.554.273 (Pada tahun 2010, Sumber data PT. ASDP Indonesia Ferry Cabang Lembar).

Tabel 3.8 Total Biaya Variabel KMP Roditha Biaya Variabel (VC) Nilai (Rp)

1. Beban Operasional Rp. 4.154.934.990,-

2. Beban Pemeliharaan Rp. 2.773.554.273,-

Total Rp. 6.928.489.263,-

Rata - rata Biaya Variabel (VC) perbulan

$$
\begin{aligned}
& = \\
& = \\
& =
\end{aligned}
$$

Dilihat dari Tabel 3.6 dan 3.7 diperoleh rata - rata Biaya Variabel KMP Roditha yaitu Rp. 577.374.105,- (Pada tahun 2010, Sumber data PT. ASDP Indonesia Ferry Cabang Lembar).

Tabel 3.9 Biaya Tetap dan Biaya Variable KMP. Roditha

\begin{tabular}{llll}
\hline Bulan & $\begin{array}{l}\text { Trip } \\
\text { (Akumulasi) }\end{array}$ & $\begin{array}{l}\text { Biaya tetap } \\
\text { (FC) }\end{array}$ & $\begin{array}{l}\text { Akumulasi } \\
\text { Biaya } \\
\text { Variabel }\end{array}$ \\
\hline Januari & 42 & Rp. 2.142.801.759 & Rp. 577.374 .105 \\
Februari & 84 & - & Rp. 1.154.748.210 \\
Maret & 126 & - & Rp. 1.732.122.315 \\
April & 168 & - & Rp. 2.309.496.420 \\
Mei & 210 & - & Rp. 2.886.870.525 \\
Juni & 252 & - & Rp. 3.464.244.630 \\
Juli & 294 & - & Rp. 4.041.618.735 \\
Agustus & 336 & - & Rp. 4.618.992.840 \\
September & 378 & - & Rp. 5.168.872.940 \\
Oktober & 420 & - & Rp. 5.773.741.050 \\
November & 462 & - & Rp. 6.351.115.155 \\
Desember & 504 & - & Rp. 6.928.489.260 \\
\hline
\end{tabular}

Total Biaya Variabel KMP. Roditha Pada Tahun 2010 yaitu Rp. 6.928.489.260,(Pada tahun 2010, Sumber data PT. ASDP Indonesia Ferry Cabang Lembar).

\subsection{Analisa Pendapatan KMP Roditha PT. ASDP Indonesia Ferry Cabang Lembar \\ 1. Jumlah Perjalanan dan Pendapatan kotor KMP Roditha \\ Total Perjalanan (Trip) KMP Roditha} Lembar - Padang bai (PP) pada tahun 2010 yaitu 504 perjalanan, di pengaruhi oleh faktor cuaca / musim dan doking tahunan KMP. Roditha. Komponen hasil pendapatan KMP. Roditha ditampilkan dalam table 3.10.

\begin{tabular}{|c|c|}
\hline Komponen pendapatan & Nilai \\
\hline $\begin{array}{l}\text { a. Penumpang } \\
\text { 1. Dewasa }\end{array}$ & Rp. 36.000 \\
\hline 2. Anak - anak & Rp. 24.000 \\
\hline \multicolumn{2}{|l|}{ b. Kendaraan } \\
\hline 1. Gol. I (Sepeda Dayung) & Rp. 52.000 \\
\hline 2. Gol. II $(\mathrm{SPM}<500 \mathrm{cc})$ & Rp. 101.000 \\
\hline 3. Gol. III (Bemo, SPM >500cc) & Rp. 232.000 \\
\hline $\begin{array}{l}\text { 4. Gol. IV PNP (Sedan, } \\
\text { Minicab, Minibus s/d } 5 \mathrm{~m} \text { ) }\end{array}$ & Rp. 659.000 \\
\hline 5. Gol. IV BRG (Pickup s/d $5 \mathrm{~m}$ ) & Rp. 617.000 \\
\hline $\begin{array}{l}\text { 6. Gol. V PNP (Bus Sedang s/d } \\
7 \mathrm{~m} \text { ) }\end{array}$ & Rp. 1.279 .000 \\
\hline $\begin{array}{l}\text { 7. Gol. V BRG (Truck Sedang, } \\
\text { Mobil Tangki s/d } 7 \mathrm{~m} \text { ) }\end{array}$ & Rp. 1.040 .000 \\
\hline $\begin{array}{l}\text { 8. Gol. VI PNP (Bus Besar } 7 \mathrm{~s} / \mathrm{d} \\
10 \mathrm{~m} \text { ) }\end{array}$ & Rp. 2.168.000 \\
\hline $\begin{array}{l}\text { 9. Gol. VII (Truk Tronton, } \\
\text { Tangki, Kereta penarik } 10 \mathrm{~s} / \mathrm{d} \\
12 \mathrm{~m} \text { ) }\end{array}$ & Rp. 1.716 .000 \\
\hline $\begin{array}{l}\text { 10. Gol. VII (Truk Tronton, } \\
\text { Tangki, Kereta penarik } 10 \mathrm{~s} / \mathrm{d} \\
12 \mathrm{~m} \text { ) }\end{array}$ & Rp. 2.200 .000 \\
\hline $\begin{array}{l}\text { 11. Gol. VIII (Truk Tronton, } \\
\text { Tangki,Alat Berat Kereta } \\
\text { penarik dgn ukuran }<12 \mathrm{~m} \text { ) }\end{array}$ & Rp. 3.286 .000 \\
\hline
\end{tabular}

Tabel 3.10 Komponen hasil pendapatan KMP Roditha. 
Tabel 3.11 Data Hasil Penumpang di tahun 2010.

\begin{tabular}{lll}
\hline No & Jenis Penumpang & Jumlah \\
\hline 1. & Orang Dewasa & 4.790 \\
2. & Orang Anak Anak & 232 \\
3. & Ken. Gol I & 23 \\
4. & Ken. Gol II & 7.985 \\
5. & Ken. Gol III & 15 \\
6. & Ken. Gol IV Penumpang & 1.751 \\
7. & Ken. Gol IV Barang & 497 \\
8. & Ken. Gol V Penumpang & 22 \\
9. & Ken. Gol V Barang & 2.453 \\
10. & Ken. Gol VI Penumpang & 434 \\
11. & Ken. Gol VI Barang & 3.055 \\
12. & Ken. Gol VII & 289 \\
13. & Ken. Gol VIII & 46 \\
\hline
\end{tabular}

Gambar 3.1 Grafik data penumpang di tahun 2010

Besarnya pendapatan kotor yang dihasilkan oleh KMP Roditha dari penjualan tiket pada tahun 2010 adalah Rp. 12.007.178.916 (Sumber data PT. ASDP Indonesia Ferry Cabang Lembar).

Tabel 3.12 Pendapatan Total rata-rata KMP Roditha

\begin{tabular}{|c|c|c|c|c|c|}
\hline TRIP & FC & & VC(Akumulasi) & TC & TR(Akumulasi) \\
\hline 0 & Rp 2.142.801.759 & & $\mathrm{Rp}$ & Rp 2.142.801.759 & $\mathrm{Rp}$ \\
\hline 42 & $\mathrm{Rp}$ & - & 577.374 .105 & Rp 2.720.175.864 & 1.000 .598 .243 \\
\hline 84 & $\mathrm{Rp}$ & - & Rp 1.154.748.210 & Rp 3.297.549.969 & 2.001.196.486 \\
\hline 126 & $\mathrm{Rp}$ & - & Rp 1.732.122.315 & Rp 3.874.924.074 & 3.001 .794 .729 \\
\hline 168 & $\mathrm{Rp}$ & - & Rp 2.309.496.420 & Rp 4.452.298.179 & 4.002.392.972 \\
\hline 210 & $\mathrm{Rp}$ & - & Rp 2,886,870,525 & Rp 5.029.672.284 & 5.002 .991 .215 \\
\hline 252 & $\mathrm{Rp}$ & - & Rp 3.464.244.630 & Rp $5,607,046,389$ & 6.003 .589 .458 \\
\hline 294 & $\mathrm{Rp}$ & - & Rp 4.041.618.735 & $\operatorname{Rp} 6.184 .420 .494$ & 7.004.187.701 \\
\hline 336 & $\mathrm{Rp}$ & - & Rp 4.618.992.840 & Rp 6.761.794.599 & 8.004 .785 .944 \\
\hline 378 & $\mathrm{Rp}$ & - & Rp 5.168.872.940 & $\operatorname{Rp} 7,311,674,699$ & $\operatorname{Rp} \quad 8.957 .736 .651$ \\
\hline 420 & $\mathrm{Rp}$ & - & $\operatorname{Rp} 5.773 .741 .050$ & Rp 7.916.542.809 & Rp 10.005.982.430 \\
\hline 462 & $\mathrm{Rp}$ & - & Rp 6.351.115.155 & Rp 8.493.916.914 & Rp 11.006.580.673 \\
\hline 504 & $\mathrm{Rp}$ & - & $\operatorname{Rp}$ 6.928.489.260 & Rp 9.071.291.019 & $\operatorname{Rp} 12.007 .178 .916$ \\
\hline
\end{tabular}

PENUMPANG TAHUN 2010

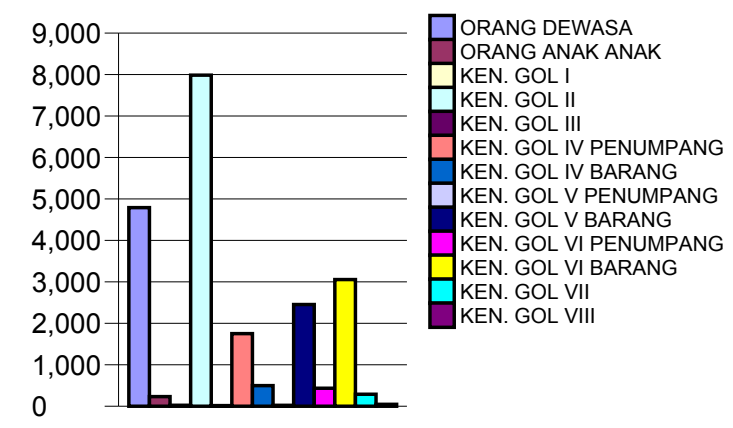


Dilihat pada tabel 3.12 diperoleh rata-rata Pendapatan (TR), sebagai berikut:

$\operatorname{TR}($ rata-rata $)=$ Rp. 12.007.178.916,00 per tahun

$=$ Rp. 1.000.598.243 rata-rata per bulan

Sehingga didapatkan rata-rata pendapatan KMP. Roditha Rp. 1.000.598.243,-/bulan (Sumber data PT. ASDP Indonesia Ferry Cabang Lembar).

3.3 Analisa Break Event Point (BEP) KMP Roditha PT. ASDP Indonesia Ferry Cabang Lembar

Berdasarkan data biaya yang telah didapatkan dan pendapatan yang telah di ketahui dalam perjalanan KMP Roditha lintas Lembar - Padang bai, selanjutnya akan digunakan sebagai data untuk menganalisa apakah usaha tersebut layak atau tidak layak ditinjau dari analisa break even point pada tabel di bawah ini. 
Tabel 3.13 Rata-rata Pengeluaran (TC) dan Pendapatan (TR).

\begin{tabular}{|c|c|c|c|c|}
\hline Bulan & Trip(Akumulasi & TC & & TR(Akumulasi) \\
\hline- & 0 & Rp 2.142.801.759 & Rp & 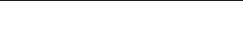 \\
\hline Januari & 42 & Rp 2.720.175.864 & $\mathrm{Rp}$ & 1.000 .598 .243 \\
\hline Februari & 84 & Rp 3.297.549.969 & $\mathrm{Rp}$ & 2.001.196.486 \\
\hline Maret & 126 & Rp 3.874.924.074 & $\mathrm{Rp}$ & 3.001 .794 .729 \\
\hline April & 168 & Rp 4.452.298.179 & $\mathrm{Rp}$ & 4.002.392.972 \\
\hline Mei & 210 & Rp 5.029.672.284 & $\mathrm{Rp}$ & 5.002 .991 .215 \\
\hline Juni & 252 & Rp 5,607,046,389 & $\mathrm{Rp}$ & 6.003 .589 .458 \\
\hline Juli & 294 & Rp 6.184.420.494 & $\mathrm{Rp}$ & 7.004.187.701 \\
\hline Agustus & 336 & Rp 6.761.794.599 & $\mathrm{Rp}$ & 8.004 .785 .944 \\
\hline September & 378 & Rp 7,311,674,699 & $\mathrm{Rp}$ & 8.957.736.651 \\
\hline Oktober & 420 & Rp 7.916.542.809 & $\mathrm{Rp}$ & 10.005 .982 .430 \\
\hline November & 462 & Rp 8.493.916.914 & $\mathrm{Rp}$ & 11.006 .580 .673 \\
\hline Desember & 504 & Rp 9.071.291.019 & $\mathrm{Rp}$ & 12.007 .178 .916 \\
\hline
\end{tabular}

Analisa ini penting dilakukan untuk memberikan rekomendasi bagi pelaku usaha apakah usaha menguntungkan dan dapat mengetahui nilai break even point yang didapatkan dari pembagian biaya tetap dengan keuntungan bersih perTrip. Perhitungannya sebagai berikut :

$$
\begin{aligned}
& \mathrm{C}=\mathrm{VC} / \mathrm{Trip} \\
& \text { = Rp. 6.928.489.260,- / } 504 \\
& =\text { Rp. } 13.747 .002,05,-(1 \text { kali perjalanan/Trip }) \\
& \mathrm{P}=\mathrm{TR} / \mathrm{Trip} \\
& \text { = Rp. 12.007.178.916,- / } 504 \\
& =\text { Rp. } 23.823 .767,69,-(1 \text { kali perjalanan/Trip }) \\
& \mathrm{VC}=\mathrm{c} \cdot \mathrm{X} \\
& =\text { Rp. } 13.747 .002,5 \times 213 \\
& =\text { Rp. 2.914.364.530,- } \\
& \mathrm{TC}=\mathrm{FC}+\mathrm{VC} \\
& =\text { Rp. } 2.142 .801 .759+R p .2 .928 .111 .532,- \\
& =\text { Rp. 5.070.913.291,5,- } \\
& \begin{aligned}
\text { TR } & =\text { p.X } \\
& =\text { Rp. } 23.823 .767,69 \times 213 \\
& =\text { Rp. } 5.074 .462 .517,97,-
\end{aligned} \\
& \begin{aligned}
\operatorname{BEP}(X) & = \\
& =
\end{aligned} \\
& B E P(X)=212,64 \approx 213 \text { Trip }
\end{aligned}
$$

Berdasarkan perhitungan didapatkan nilai rata-rata yaitu 213 Trip. Untuk Grafik break even point dalam rata-rata perjalanan ditunjukan oleh gambar 3.2.

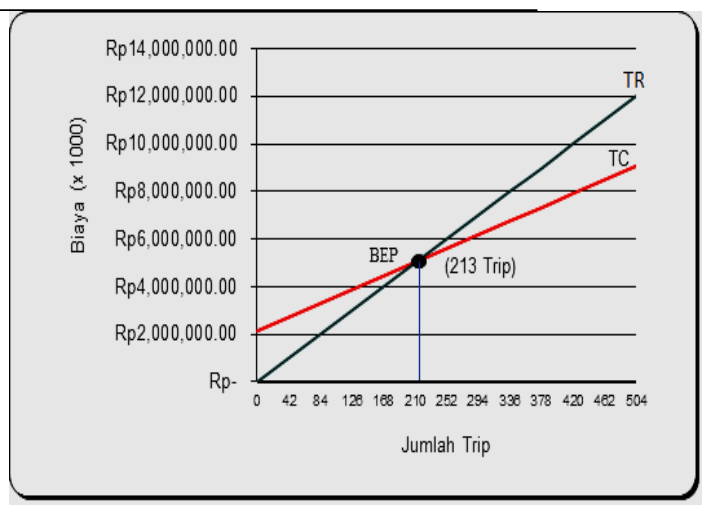

Gambar 3.2 Grafik BEP Hasil Penelitian

Pada gambar 3.2 jika titik BEP ke kiri maka KMP Rodita cepat mengalami keuntungan dan jika titik BEP ke kanan KMP Rodita dalam waktu lama mengalami keuntungan, hingga nilai break even point yang di dapat pada bulan ke 5 yaitu pada trip ke 213 di tahun 2010. Titik ini KMP Roditha tidak mengalami kerugian dan tidak pula mendapatkan keuntungan, sehingga KMP Roditha dinyatakan layak beropersi

\section{KESIMPULAN}

Dari analisis dan pembahasan diatas, maka dapat diambil beberapa kesimpulan sebagai berikut :

1. Besarnya pendapatan yang dihasilkan oleh KMP Roditha dari penjualan tiket pada tahun 2010 adalah Rp. 12.007.178.916 (Sumber data PT. ASDP Indonesia Ferry Cabang Lembar).

2. Untuk analisa data kuantitatif digunakan rumus break even point untuk mengetahui nilai impas dari pengeluaran dan pendapatan pada KMP Roditha. Nilai break even point yang di dapatkan pada 
213 Trip di Tahun 2010, yaitu total biaya pengeluaran (TC) sama dengan total pendapatan (TR).

3. Berdasarkan Tahun 2010 KMP Roditha dinyatakan layak beroperasi pada bulan ke 5 bisa mencapai break even point.

\section{DAFTAR PUSTAKA}

[1] Alwi, Syafaruddin, 1994, Alat-Alat Analisa Dalam Pembelanjaan, Edisi Revisi. Andi Offset, Yogyakarta.

[2] Anonim, 2009, peranan-analisis-breakeven-point, http://expressclass.blogspot.com. (diakses tanggal 15 April 2011)

[3] Doumard, John. M., 1975, Manajemen Kapal, FairPlay Publication.

[4] Himayati, Rosita, 2010, Studi kelayakan penggunaan mesin diesel menggunakan metode break even point pada PLTD Labuhan Sumbawa besar, Skripsi Jurusan Teknik mesin Fakultas Teknik Universitas Mataram, Mataram.
[6] Pujawan, I nyoman, 1995, Ekonomi Teknik, PT. Guna Widya.

[7] Salim, Abbas, 1997, Manajemen Transportasi, PT Raja Grafindo Persada. Jakarta.

[8] Sigit, Soehardi, 1987, Analisa Break Even Point, BPFE, Yogyakarta.

[9] Wahyudiana, Yadi, 2009, Studi kelayakan penggunaan traktor tangan di kecamatan lingsar kabupaten lombok barat, Skripsi Jurusan Teknik mesin Fakultas Teknik Universitas Mataram, Mataram.

[10] Weston, J. Fred dan Thomas E. Copeland, 1995, Manajemen Keuangan, Terjemahan Jilid I, Bina Rupa Aksara, Jakarta.

[5] Nasution, Arman Hakim, 2005, Manajemen Industri, Andi Offset, Yogyakarta. 